\title{
Masalah Pengajaran Bahasa Arab di Madrasah Aliyah di Jakarta
}

\author{
Nur Hizbullah, Zaqiatul Mardiah \\ Program Studi Sastra Arab, Fakultas Sastra \\ Universitas Al Azhar Indonesia, Jl. Sisingamangaraja, Jakarta 12110 \\ Penulis untuk korespondensi/E-mail: nurhz@uai.ac.id
}

\begin{abstract}
Abstrak - Bahasa Arab diajarkan sebagai salah satu mata pelajaran penting di Madrasah Aliyah dalam struktur kurikulum studi keislaman. Meskipun penting, bahasa Arab hanya diajarkan dalam jumlah jam yang terbatas dan banyak memiliki permasalahan. Penelitian deskriptif ini bertujuan memetakan masalah pengajaran bahasa Arab di Madrasah Aliyah di wilayah Jakarta. Permasalahan pengajaran bahasa Arab berkisar pada masalah motivasi dan minat siswa dalam mempelajari bahasa Arab. Kondisi itu ditambah dengan perbedaan pengetahuan dan pengalaman belajar mereka karena latar pendidikan mereka yang berbeda pula. Masalah lain yang muncul adalah ketersediaan sarana penunjang belajar bahasa Arab dan pemanfaatannya. Di samping itu, kompetensi guru yang tidak seragam dan tidak standar menjadi kendala pula dalam proses pengajaran. Itu kemudian berdampak pada kemampuan metodologis mereka dalam mengajar bahasa Arab di kelas. Di sisi lain, minimnya waktu belajar di sekolah membuat sulitnya pengembangan pengajaran bahasa Arab secara lebih luas, ditambah lagi dengan sulitnya penciptaan lingkungan berbahasa yang kuat di sekolah. Semua permasalahan itu bertalian satu sama lain dan membutuhkan penyelesaian yang komprehensif dan berkelanjutan.
\end{abstract}

Abstract - Arabic is taught as one of the important subjects in Madrasah Aliyah in Islamic studies curriculum structure. Although it's important, the Arabic language is taught only in a limited number of hours and has many problems. This descriptive study aimed to map the problem of teaching Arabic at Madrasah Aliyah in Jakarta. The problem of teaching Arabic revolves around the question of motivation and interest of students in learning Arabic. The condition is coupled with differences in knowledge and experience of their learning because of their difference of educational background. Another problem that arises is the availability of means of supporting learning Arabic and utilization. In addition, the teacher competency standards are not same and not a constraint also in the teaching process. It was then impact on their methodological ability in teaching Arabic in the classroom. On the other hand, lack of time to learn in school makes it difficult to develop the teaching of Arabic language more broadly, coupled with the difficulty of creating an environment that is strong language in school. All the problems were related to each other and require a comprehensive and sustainable settlement.

Keywords: Arabic language teaching, teaching problems, Madrasah Aliyah

\section{PENDAHULUAN}

$\mathrm{D}$ unia ilmu pengetahuan sudah sejak lama diramaikan dengan ramainya perdebatan tentang sekulerisasi ilmu pengetahuan. Pada abad pertengahan, karena dipengaruhi situasi sosialpolitik regional di Eropa, mencuatlah gagasan untuk memisahkan ilmu pengetahuan dari agama. Isu itu berhembus kuat ke tengah masyarakat dunia dan tidak sedikit masyarakat yang terpengaruh dan mengikuti paham tersebut. Dunia Barat bahkan kini sudah menjadi contoh nyata dan konsisten bagaimana dunia ilmu pengetahuan jauh terpisah dari norma-norma keagamaan.

Pandangan sebaliknya secara nyata dan konsisten dianut oleh Islam. Agama ini sama sekali tidak mengenal pemisahan antara nilai-nilai keagamaan dengan ilmu pengetahuan. Yang ada malah kesatupaduan yang utuh antara dua hal tersebut. Alquran sebagai kitab suci kemudian oleh para intelektual muslim dijadikan sebagai rujukan utama 
bagi pengembangan ilmu pengetahuan, baik ilmu tentang keislaman itu sendiri maupun ilmu tentang kealamsemestaan.

Di dalam studi Islam, terdapat sekian banyak cabang ilmu yang saling terkait dan menunjang. Jika ditelusuri lebih jauh, semua cabang ilmu dalam Islam bersumber pada satu rujukan utama, yaitu Alquran. Sebagai "buku induk" bagi ilmu pengetahuan yang dikembangkan dalam kerangka islami, Alquran yang berbahasa Arab juga mengharuskan semua ilmu pada awal pengembangannya menggunakan bahasa Arab sebagai bahasa pengantar bagi sejumlah besar kitab ilmu pengetahuan dan bahkan teknologi. Situasi itu alhasil membawa bahasa Arab ke tempat yang lebih penting dan terhormat dalam ranah dan struktur ilmu pengetahuan.

Pentingnya bahasa Arab kemudian membuka jalan bagi lembaga pendidikan untuk memberikan pengajaran bahasa Arab bagi peserta didik. Dalam mengkaji bidang ilmu apa pun, para pelajar diharuskan menguasai bahasa Arab sebagai elemen dasar bagi penguasaan ilmu pengetahuan di tahap berikutnya. Dalam kajian Islam, utamanya, pembelajaran dan penguasaan bahasa Arab mutlak diperlukan. Itulah dasar bagi lembaga pendidikan Islam untuk menempatkan bahasa Arab dalam posisi yang penting.

Sebagai cabang ilmu yang berdiri sendiri, bahasa Arab memiliki sistematika dan struktur yang khas. Pembelajaran bahasa Arab secara umum sama seperti pembelajaran bahasa asing lainnya, yaitu bertujuan mencapai empat ragam kemahiran, yaitu menyimak, berbicara, membaca, dan menulis. Kemahiran itu dicapai dengan proses pembelajaran yang melibatkan unsur-unsur penting seperti kurikulum, bahan ajar, guru, metode pengajaran dan pembelajaran, serta fasilitas pembelajaran.

Keseluruhan unsur tersebut berperan penting dalam proses pembelajaran. Para pihak terkait, seperti guru dan sekolah, bertanggung jawab atas pemenuhan dan ketersediaan unsur-unsur yang dapat menyukseskan proses pembelajaran bahasa Arab di sekolah.

Madrasah Aliyah adalah salah satu jenjang pendidikan menengah Islam di Indonesia. Di sekolah itu, bahasa Arab diajarkan sebagai salah satu mata pelajaran penunjang penguasaan materimateri studi Islam. Sebagai mata pelajaran penting, bahasa Arab sudah semestinya mendapat perhatian dan penanganan yang sebaik-baiknya.

Dalam pengajarannya di sekolah, bahasa Arab ternyata juga menjadi salah satu pelajaran yang cukup banyak menghadapi masalah. Sebagai gambaran, salah satu penelitian di Kementerian Agama menyebutkan, bahkan pada kompetensi dasar berupa kemahiran membaca yang menjadi inti pembelajaran di Madrasah Aliyah, kemampuan siswa pada aspek tersebut cukup rendah. Hal itu bertali-temali dengan berbagai faktor yang mempengaruhinya, seperti kebijakan kepada Madrasah, ketersediaan saran dan bahan penunjang pembelajaran bahasa Arab, kualitas siswa saat masuk Madrasah, kualifikasi dan penguasaan praktik pengajaran oleh guru, serta proses pembelajaran yang dijalani siswa di dalam maupun di luar kelas [1].

Masalah yang terjadi umumnya berkisar antara masalah kebahasaan dan masalah nonkebahasaan. Lebih lanjut, Fiddaroini [2] memetakan masalah pengajaran bahasa Arab ke dalam dua kelompok besar, yaitu :

1. Faktor linguistik, yang mencakup beberapa aspek berupa :

a. perbedaan karakteristik bahasa satu sama lain, termasuk perbedaan mendasar pada sistem gramatikanya, sebagaimana yang pernah dikemukakan oleh Alim [3],

b. perbedaan secara khusus antara bahasa Arab dan bahasa Indonesia. Fiddaroini sependapat dengan Saadah [4] mengenai hal ini;

c. perbedaan yang lebih spesifik lagi dalam hal sistem bunyi dan sistem lambang (tulisan) bahasa antara satu dan lainnya, seperti yang dibahas oleh Masduki [5].

2. Faktor nonlinguistik. Fiddaroini juga sependapat dengan gagasan yang menyebutkan bahwa hal itu antara lain berkisar pada masalah kemampuan peserta didik dengan faktor-faktor psikologisnya [3] dan perbedaan kondisi sosialbudaya masyarakat Arab sebagai penutur asli bahasa tersebut dengan kondisi pembelajar Indonesia, juga masalah sarana dan prasarana fisik, tempat, dan waktu belajar bahasa Arab [5].

Secara luas dapat diidentifikasikan bahwa masalah nonlinguistik seringkali lebih kompleks dirasakan di banyak lembaga pendidikan. Hal itu pastinya berimbas pada terganggunya proses pembelajaran dan ujungnya pencapaian siswa terhadap target belajar. 
Mengingat besar dan luasnya cakupan masalah dalam pembelajaran bahasa Arab yang dihadapi oleh para guru bahasa Arab di Madrasah Aliyah perlu kiranya dipetakan lalu dicarikan solusinya. Para guru dan lembaganya perlu menyadari pentingnya proses pemecahan terhadap masalah yang ada secara institusional. Penanganan masalah pengajaran bahasa Arab kiranya dapat dilakukan melalui bekerja sama dengan pihak lain. Dalam hal ini, lembaga pendidikan tinggi atau universitas kiranya dapat dijadikan mitra kerja sama dalam pemecahan masalah pengajaran bahasa Arab di Madrasah. Oleh karena itu, penelitian ini memandang pentingnya pendalaman terhadap masalah pengajaran bahasa Arab di Madrasah Aliyah, khususnya yang berada di wilayah DKI Jakarta.

Berdasarkan latar permasalahan tersebut, penelitian ini bertujuan mendapatkan gambaran tentang masalah pengajaran bahasa Arab di Madrasah Aliyah di Jakarta, khususnya pada masalah nonkebahasaan. Penelitian ini diharapkan bermanfaat memberikan informasi yang menyeluruh tentang peta masalah yang terjadi dalam pengajaran bahasa Arab di Madrasah Aliyah di Jakarta sebagai masukan evaluasi bagi pimpinan dan manajemen Madrasah Aliyah yang bersangkutan tentang komitmen dukungan bagi pengajaran bahasa Arab yang berkualitas di Madrasahnya.

Oleh karena masalah dalam pengajaran bahasa Arab sangatlah luas, yaitu kebahasaan dan nonkebahasaan, maka penelitian ini dibatasi pada aspek masalah nonkebahasaan saja, sebagai salah satu lingkup masalah yang ada dalam pengajaran bahasa Arab. Masalah kebahasaan tidak dibahas karena terlalu luas dan mencakup unsur-unsur sosiologis yang kompleks. Sementara itu, pembahasan masalah nonkebahasaan dipilih karena penelitian ini ingin memfokuskan pembahasan pada aspek yang melibatkan sekolah semata. Dengan batasan pada masalah nonkebahasaan, diharapkan penelitian ini dapat terfokus pada suatu aspek secara mendalam.

\section{KAJIAN TEORI}

Pada prosesnya, pengajaran bahasa Arab di level pendidikan mana pun sesungguhnya sangatlah kompleks. Kompleksitas itu kemudian menimbulkan masalah. Pada hakikatnya, masalah berada mulai pada pihak-pihak yang terlibat dalam pengajaran, seperti guru dan siswa sebagai yang utama serta pihak terkait lainnya seperti kepala sekolah dan tenaga kependidikan penunjang, sampai pada hubungan satu sama lain. Melihat luasnya kompleksitas masalah pada proses pengajaran bahasa Arab, maka pada penelitian ini hanya akan dilihat permasalahan yang terjadi pada proses pembelajaran yang melibatkan guru dan siswa serta proses pembelajaran di sekolah saja.

Secara umum, teori tentang masalah pengajaran bahasa Arab sangatlah beragam. Berbagai teori itu didasarkan pada jenis-jenis masalah yang terdapat dalam suatu lingkungan tempat berlangsungnya proses pembelajaran bahasa Arab.

Menurut Fakhrurrozi dan Mahyudin, masalah yang terjadi pada pembelajaran bahasa Arab dapat dibagi ke dalam dua kelompok besar, yaitu masalah kebahasaan dan masalah nonkebahasaan [6].

\section{Masalah Kebahasaan}

Pada tataran ini, masalah yang berkenaan dengan kebahasaan mencakup :

1. problem bunyi, tentang jenis-jenis bunyi huruf Arab dan cara melafalkannya dengan baik dan benar;

2. problem kosakata, tentang sejumlah kata dalam bahasa Arab yang berkaitan dengan topik pembelajaran yang harus diketahui dan dimengerti artinya dalam bahasa Indonesia, dan

3. problem tata kalimat, tentang bagaimana menyusun kalimat bahasa Arab yang benar secara gramatikal dan sesuai dengan konteks wacana.

\section{Masalah Nonkebahasaan}

Pada lingkup ini, masalah mencakup aspek-aspek berikut.

1. Masalah motivasi dan minat siswa dalam belajar bahasa Arab. Dari sisi siswa, motivasi merupakan hal penting yang berkaitan langsung dengan perilaku belajarnya dan hasil pembelajaran. Motivasi siswa dapat muncul baik dari dalam dirinya sendiri sebagai buah dari pengalaman belajar yang positif di masa sebelumnya maupun dari luar dirinya berupa orangtua, keluarga, lingkungan sekolah, lingkungan masyarakat, dan sebagainya. Motivasi siswa ini harus senantiasa ditumbuhkan dan dijaga agar siswa menyukai bahasa Arab dan lalu mencapai hasil yang baik dari pembelajaran.

2. Masalah perbedaan individu siswa dalam satu kelas, dari segi kemampuan maupun orientasi 
belajarnya. Kemampuan berbahasa Arab siswa dalam suatu kelas tentunya beragam, antara lain karena ada siswa yang sudah pernah belajar bahasa Arab di masa pendidikan sebelum sekolahnya yang sekarang dan ada siswa yang baru belajar bahasa Arab pada periode sekolahnya yang sekarang. Selain itu, kemampuan berbahasa Arab siswa yang samasama memulai belajar dari kelas dan waktu yang sama pun berbeda bergantung pada pencapaiannya masing-masing. Orientasi belajar siswa pun beragam sesuai dengan pandangan pribadinya ataupun tujuan hidupnya sendirisendiri.

3. Masalah sarana dan prasarana penunjang pengajaran. Masalah ini bisa terjadi pada sekolah yang sudah memiliki ataupun belum memiliki sarana dan prasarana penunjang pengajaran yang baik. Pada sekolah yang dilengkapi sarana dan prasarana yang baik, masalah dapat terjadi bila pemanfaatannya tidak optimal, sehingga siswa tidak mendapatkan keuntungan dari ketersediaan fasilitas itu. Adapun sekolah yang belum memiliki sarana dan prasarana pengajaran yang memadai, biasanya lebih menekankan pengajaran bahasa Arab dengan pendekatan dan metode konvensional serta alat bantu yang seadanya. Dengan demikian, situasi pengajaran cenderung tidak memberikan motivasi yang kuat bagi peserta didik, kecuali jika faktor guru cukup baik untuk mengatasi persoalan ini.

4. Kompetensi guru secara akademik, pedagogik, personal, dan sosial. Secara ideal, guru bahasa Arab selayaknya berasal dari latar belakang akademik jurusan atau program studi Pendidikan Bahasa Arab, atau sekurangkurangnya dari jurusan Bahasa dan Sastra Arab. Ada pula latar guru yang berasal dari lembaga pendidikan menengah semisal pondok pesantren atau madrasah, namun tidak memiliki jenjang kesarjanaan di bidang bahasa Arab. Kompetensi akademik kebahasaaraban sesungguhnya menjamin kemampuan pedagogik guru dalam mengajarkan bahasa Arab kepada para siswanya. Di samping itu, kompetensi personal dan sosial guru penting dalam rangka menunjang tugasnya mengajar dan membina siswa dalam bidang ilmu yang diajarkannya.

5. Metode pengajaran yang digunakan. Metode memegang peranan penting dalam proses pengajaran kepada siswa. Guru memiliki kuasa penuh untuk memilih metode yang paling tepat digunakannya dalam mengajarkan bahasa Arab, bergantung pada situasi kelas, kondisi setiap siswa, latar sosial maupun ekonomi siswa, kultur masyarakat setempat, dan tentunya ketersediaan alat bantu pengajaran di sekolah yang bersangkutan. Guru diharapkan tidak kaku dalam memilih dan menerapkan metode pengajaran agar dapat mencapai hasil pembelajaran yang maksimal dari siswanya dan mencapai tujuan pengajaran yang dicanangkan.

6. Waktu pengajaran yang tersedia di dalam dan di luar kelas. Jumlah jam belajar di dalam kelas amat menentukan pencapaian hasil belajarmengajar. Oleh karena itu, penambahan waktu belajar di luar kelas amat dimungkinkan guna meningkatkan kuantitas maupun kualitas hasil belajar-mengajar yang lebih optimal. Kegiatan di luar kelas dapat dikemas dalam bentuk kegiatan ekstrakurikuler yang beragam dan dapat meningkatkan minat siswa dalam belajar bahasa Arab

7. Lingkungan berbahasa yang mendukung kemampuan siswa. Dalam pengajaran bahasa Arab, kelas bukan satu-satunya tempat belajar. Perlu ada lingkungan dalam pengertian yang lebih luas untuk mendukung pencapaian hasil belajar bahasa Arab yang lebih maksimal. Lingkungan dapat diciptakan dan dibentuk, seperti berupa kegiatan tambahan, penggunaan fasilitas tertentu untuk keperluan pembelajaran, pembentukan budaya komunikasi dalam bahasa Arab, dan cara-cara lain yang sangat beragam.

\section{METODE PENELITIAN}

Penelitian ini bersifat deskriptif-kualitatif yaitu menguraikan secara ilmiah temuan informasi tentang situasi dan masalah pengajaran bahasa Arab di Madrasah Aliyah di Jakarta. Subjek penelitian ini guru bahasa Arab yang berasal dari 77 Madrasah Aliyah Negeri maupun swasta yang ada di Jakarta. Mereka dipilih selaku pengajar di kelas yang terlibat langsung pada proses pengajaran.

Data diperoleh dengan metode studi kepustakaan yang diperkuat dengan wawancara kepada sejumlah guru serta melalui angket. Data temuan penelitian lebih dulu dicatat lalu dianalisis secara deskriptif dan diinterpretasikan untuk kemudian disimpulkan secara induktif dan kualitatif. 


\section{HASIL DAN PEMBAHASAN}

\section{Masalah Motivasi dan Minat Siswa dalam Belajar Bahasa Arab}

Sebagai pelaku proses belajar, siswa kini menjadi pusat orientasi. Hal itu dikenal dengan istilah "pembelajaran berpusat pada siswa". Hal itu merupakan antitesis dari pendapat lama "pembelajaran berpusat pada guru". Oleh karena itu, situasi siswa dalam proses pengajaran sangat penting untuk diperhatikan agar mereka dapat menjalani pembelajaran dengan baik dan hasil yang optimal.

Dari sudut pandang guru, motivasi dan minat siswa belajar bahasa Arab di Madrasah Aliyah berkaitan dengan pengalaman belajar mereka di sekolah tingkat sebelumnya. Secara umum, menurut para guru, jumlah siswa Madrasah Aliyah yang berasal dari Madrasah Tsanawiyah dan juga Pondok Pesantren sedikit lebih besar dibandingkan dengan mereka yang berasal dari Sekolah Menengah Pertama. Apabila siswa Madrasah Aliyah berasal dari Madrasah Tsanawiyah dan/atau Pondok Pesantren dan pernah belajar bahasa Arab di sekolah tersebut, maka dia cenderung mudah, termotivasi, dan berminat terhadap pelajaran bahasa Arab di Madrasah Aliyah. Sebaliknya, jika siswa Madrasah Aliyah baru belajar bahasa Arab di level ini karena dia lulusan Sekolah Menengah Pertama umum/nonagama, dia pasti menghadapi kesulitan tersendiri mempelajari bahasa Arab karena merupakan pengalaman pertama baginya dan motivasi serta minatnya berbeda dari teman-teman lainnya dari kelompok pertama. Pada tataran ini, para guru harus menghadapi siswa yang terbagi ke dalam dua kelompok besar, yaitu kelompok siswa yang sudah mengenal bahasa Arab dan berminat serta termotivasi mempelajarinya, dan kelompok siswa lain yang baru mengenal bahasa Arab dan kurang berminat serta kurang termotivasi mempelajarinya.

Sesungguhnya, motivasi dan minat belajar siswa terhadap bahasa Arab dipengaruhi oleh banyak faktor yang saling berkaitan. Namun, sekian banyak faktor itu dapatlah dikelompokkan ke dalam dua bagian, yaitu faktor khusus dan faktor umum. Faktor khusus adalah masalah internal pribadi siswa sendiri. Masalah motivasi dan minat yang tumbuh dari dalam diri siswa dapat dipengaruhi oleh antara lain persepsi siswa bahwa bahasa Arab itu sulit, latar situasi keagamaan keluarga, dan informasi siswa tentang kesan bahasa Arab di mata teman-temannya. Adapun faktor umum yang dapat mempengaruhi motivasi siswa adalah faktor luar dirinya seperti lingkungan belajar di sekitarnya yang secara langsung atau tidak mempengaruhi kekuatan motivasi dan minatnya dalam belajar bahasa Arab.

Di samping guru, terdapat informasi lain yang menyebutkan bahwa ada Kepala Madrasah yang sampai terlibat dan turun tangan memberi motivasi khusus kepada siswa agar memperhatikan pelajaran bahasa Arab sebagai sesuatu yang penting. Namun, hal itu bukan berarti mengesampingkan pentingnya mata pelajaran yang lain. Kepala Madrasah yang termasuk kelompok ini memandang bahwa bahasa Arab penting dalam kedudukannya sebagai bahasa studi Islam secara umum.

Gambaran situasi tersebut merupakan masalah tersendiri bagi para guru. Perbedaan itu memberikan tantangan bagaimana memotivasi siswa agar giat belajar bahasa Arab. Untuk itu, dalam hal motivasi, para guru menyatakan terus berupaya memberikan motivasi kepada semua siswanya agar dapat menjalani pembelajaran bahasa Arab dan mencapai hasil yang terbaik.

\section{Masalah Perbedaan individu Siswa dalam Satu Kelas dari Segi Orientasi Belajar Maupun Kemampuan Belajarnya}

Masalah ini masih ada kaitannya dengan masalah pada butir A di atas. Namun, masalah ini lebih khusus mengarah kepada orientasi belajar dan kemampuan siswa dalam bidang bahasa Arab. Seperti disinggung di atas, motivasi dan minat siswa dalam belajar bahasa Arab dilatarbelakangi oleh perbedaan latar pendidikan sebelum mereka memasuki jenjang Madrasah Aliyah. Hal itu mendasari perbedaan kemampuan dasar masingmasing siswa dalam penguasaan bahasa Arab di kelas dan juga orientasi belajarnya.

Dalam pandangan guru, para siswa Madrasah Aliyah lulusan Madrasah Tsanawiyah dan/atau Pondok Pesantren relatif lebih memahami tujuan pembelajaran bahasa Arab yang disampaikan oleh para guru. Dengan demikian, orientasi belajar mereka cukup baik untuk dapat memahami maksud yang disampaikan oleh guru mereka di kelas. Adapun siswa dari kelompok lain yang berlatar pendidikan Sekolah Menengah Pertama umum yang baru pertama kali belajar bahasa Arab membutuhkan waktu untuk dapat memiliki orientasi belajar yang sesuai dengan tujuan pembelajaran bahasa Arab itu sendiri. Siswa pada kelompok ini masih harus dipahamkan oleh guru 
tentang kedudukan dan fungsi pelajaran bahasa Arab dalam struktur kurikulum maupun keilmuan Islam. Barulah dari situ mereka dapat memahami pentingnya pelajaran bahasa Arab di Madrasah Aliyah. Perbedaan orientasi belajar ini penting untuk segera diatasi oleh para guru agar nantinya pada tahapan pengajaran hal itu tidak menghalangi siswa untuk mencapai kemampuan belajar yang diharapkan.

Kemampuan belajar siswa ditandai dengan pencapaian tujuan pembelajaran. Dalam hal ini, guru yang sudah menyiapkan rencana pengajaran kemudian melakukan proses mengajar di kelas untuk menyampaikan materi pelajaran kepada siswa. Di bagian akhir, guru melakukan evaluasi untuk menilai sejauh mana kemampuan siswa dalam menerima pelajaran yang diberikannya. Apabila siswa mampu mencapai tujuan pembelajaran, maka siswa dianggap mampu menguasai suatu materi yang telah diajarkan oleh guru. Sebaliknya, apabila siswa belum mampu mencapai tujuan pembelajaran, maka siswa tersebut dianggap tidak mampu menguasai materi. Situasi ini memang disebabkan oleh banyak faktor yang mungkin mempengaruhinya.

Dalam kaitan dengan orientasi belajar dan latar pendidikan sebelumnya, masalah ini tidak dapat saling dipisahkan. Kemampuan siswa lulusan sekolah agama Islam cenderung lebih baik ketimbang lulusan sekolah umum. Para guru menyadari, hal ini perlu mereka sikapi dengan hatihati dan bijaksana. Oleh karena itu, para guru mengaku selalu berusaha mencari cara untuk dapat menyeimbangkan atau setidaknya mendekatkan kemampuan para siswa yang kurang mahir dengan kawan-kawannya yang kemampuannya beberapa tingkat di atas mereka. Para guru berpandangan bahwa penguasaan bahasa Arab oleh siswa secara merata sangat penting sebagai pijakan bagi penguasaan ilmu-ilmu keislaman lain yang memang bersumber dan berdasar pada pustaka rujukan berbahasa Arab. Bahwa kemudian para siswa memiliki kecenderungan dan minatnya masing-masing dalam berbagai bidang ilmu keislaman maupun sains, penguasaan bahasa Arab sebagai "ilmu alat" di sekolah Islam semacam Madrasah Aliyah kepentingannya tak bisa diabaikan ataupun dikesampingkan.

Dalam hal ini, guru perlu memberi perhatian lebih dalam upaya menanamkan kesadaran akan orientasi belajar yang jelas dan pentingnya kemampuan bahasa Arab siswa yang harus dicapai oleh mereka.
Dengan demikian, pendekatan ini diharapkan mampu menyelesaikan masalah yang ada sehingga siswa dapat dibawa oleh guru kepada situasi yang ingin dicapai dalam pengajaran bahasa Arab.

\section{Masalah Sarana dan Prasarana Penunjang Pengajaran}

Di Jakarta, pada umumnya Madrasah Aliyah, terutama Madrasah Aliyah Negeri, sudah memiliki fasilitas laboratorium bahasa. Sebagian di antaranya bahkan sudah dilengkapi fasilitas multimedia dan tersambung dengan fasilitas internet. Kondisi serupa tidak terjadi pada Madrasah Aliyah Swasta yang memiliki keterbatasan finansial untuk pengadaan fasilitas pembelajaran.

Menurut para guru, laboratorium bahasa tidak semata-mata digunakan untuk pelajaran bahasa Arab, tetapi juga bahasa Inggris dan bahasa pilihan lain yang diajarkan di Madrasah yang bersangkutan. Dalam kaitan penggunaan laboratorium bahasa untuk pelajaran bahasa Arab, para guru melihat ada kendala waktu dan teknis dalam pemanfaatannya. Kendala waktu yang dialami adalah keterbatasan jumlah jam belajar di laboratorium karena pelajaran bahasa Arab harus berbagi jam dengan pelajaran lain dalam penggunaan fasilitas laboratorium. Di samping itu, kendala teknis sering kali terjadi dan menghambat proses pengajaran bahasa Arab di laboratorium. Akibatnya, guru harus mengambil langkah dengan tetap melakukan pengajaran di kelas dengan metode konvensional.

Dalam beberapa kasus malah ditemukan adanya fasilitas laboratorium yang sama sekali tak terpakai karena kendala teknis yang sulit diatasi dan membutuhkan biaya besar untuk menyelesaikannya. Pada akhirnya, daripada menghabiskan biaya besar untuk memperbaiki fasilitas laboratorium, Pimpinan Madrasah mengambil kebijakan untuk membekukan kegiatan penggunaan laboratorium tanpa ada langkah konkret untuk menyelesaikan masalah ketersediaan fasilitas yang tak termanfaatkan. Kondisi ini umumnya terjadi di Madrasah Aliyah Swasta. Selain alasan finansial, ada pula Madrasah yang nyatanya memang belum memiliki kebijakan untuk pengembangan sistem dan metode pengajaran dengan memanfaatkan fasilitas teknologi mutakhir. Hal itu harus diakui menjadi kendala bagi para guru dan juga siswa yang sejatinya punya motivasi dan minat untuk mengajar dan belajar bahasa Arab dengan pendekatan yang lebih mutakhir. 
Bagi Madrasah yang belum memiliki fasilitas laboratorium, pada umumnya para guru memanfaatkan fasilitas seadanya. Itu pun lebih dibebankan kepada guru untuk membuat, mengadakan, ataupun menciptakan sendiri sarana dan prasarana penunjang pengajaran bahasa Arab. Situasi ini sesungguhnya tidak hanya memberi tantangan kepada guru untuk mengajar secara optimal, tapi juga membuka ruang bagi kreativitas guru untuk menciptakan hal-hal baru dalam mengembangkan sistem pengajaran yang dijalankannya di Madrasah yang bersangkutan. Para guru mengakui, mereka cukup kesulitan jika harus membuat atau menciptakan sendiri sarana dan alat bantu mengajar, terutama jika material yang dibuat bersifat konvensional. Beberapa orang guru mengaku lebih mudah jika menggunakan fasilitas aplikasi presentasi (powerpoint) meskipun hal itu amat jarang dilakukan karena keterbatasan alat dan waktu membuatnya.

Di samping fasilitas laboratorium, sarana penunjang pengajaran bahasa Arab lainnya yang tak kalah penting adalah perpustakaan. Masalah seputar perpustakaan bukan pada keberadaan atau ketiadaan perpustakaan di sebuah Madrasah. Setiap Madrasah sudah memiliki perpustakaan. Namun, masalahnya adalah pada ketersediaan buku-buku penunjang dalam bahasa Arab. Menurut para guru, masalah ketersediaan buku penunjang pembelajaran bahasa Arab terkait juga dengan masalah keuangan Madrasah dan kebijakan pimpinan Madrasah dan Yayasan-bagi Madrasah Swasta-menyangkut penganggaran keuangan untuk pengembangan fasilitas pendidikan dan pengajaran di Madrasah yang bersangkutan. Hal itu tidak lepas dari mahalnya harga buku-buku berbahasa Arab di pasaran yang dapat digunakan sebagai bahan penunjang.

Untuk mengatasi hal ini, para guru mengaku menyiasatinya dengan buku-buku digital yang bisa dibaca ataupun diunduh secara gratis oleh siswa mereka atas dasar tugas-tugas tertentu yang biasa diberikan dalam pengajaran di kelas. Dari situ guru dapat memantau siapa siswa yang aktif dan mampu memanfaatkan ketersediaan sumber tersebut secara maksimal dan siapa siswa yang tidak aktif karena tidak mampu mengakses sumber digital tersebut sehingga tidak dapat pula memanfaatkannya.

\section{Kompetensi Guru Secara Akademik, Pedagogik, Personal, dan Sosial}

Idealnya, seorang guru bahasa Arab adalah seorang sarjana pendidikan bahasa Arab atau sarjana studi bahasa Arab. Lebih ideal lagi bila guru yang bersangkutan memiliki kualifikasi akademik yang lebih tinggi, yaitu jenjang magister dan doktor.

Secara umum, kualifikasi guru bahasa Arab di Madrasah Aliyah adalah Sarjana Strata 1. Namun, latar studi mereka di jenjang itu tidak seluruhnya berasal dari Pendidikan Bahasa Arab atau Bahasa dan Sastra Arab. Meskipun sebagian besar memiliki latar kualifikasi akademik dimaksud, ada beberapa guru bahasa Arab di Madrasah Aliyah, baik negeri maupun swasta, yang bukan berasal dari latar itu. Meski mereka berasal dari disiplin ilmu yang lain, sebagian guru ditugaskan mengajar bahasa Arab karena situasi tertentu sehingga mereka dianggap layak mengajar bahasa Arab, antara lain karena mereka adalah lulusan pondok pesantren atau perguruan tinggi agama Islam yang mengajarkan bahasa Arab secara umum.

Kondisi tersebut amat erat berkaitan kemudian dengan kompetensi pedagogik guru bahasa Arab dalam mengajar. Kompetensi pedagogik mutlak dimiliki seorang guru karena kompetensi itu menjamin kualitas pengajaran yang baik kepada para siswanya. Kompetensi ini penting dalam rangka penerapan proses yang dimulai dari perencanaan, pelaksanaan, sampai dengan evaluasi pengajaran bahasa Arab di kelas yang diasuhnya. Dari situ, guru dituntut untuk mengawal proses pengajaran untuk sampai kepada tujuannya. Hal itu disadari pula oleh mereka sehingga mereka mengaku berkomitmen untuk senantiasa fokus pada pencapaian tujuan dengan upaya yang bisa mereka lakukan.

Meskipun umumnya berlatar pendidikan bahasa Arab dan/atau studi bahasa Arab dari perguruan tinggi agama Islam maupun pondok pesantren, ditunjang pula dengan pengalaman mengajar selama ini, para guru merasa tetap memerlukan tambahan wawasan dan pengayaan pengalaman melalui pendidikan dan pelatihan secara berkala. Hal ini menjadi keluhan para guru mengingat minimnya ketersediaan kegiatan diklat bagi mereka di luar sekolah dan juga waktu yang tersedia untuk itu andai ada undangan mengikuti kegiatan semacam itu sampai kepada mereka. Masalah ini tidak sepatutnya terjadi dan bisa diatasi dengan kebijakan pemerintah terkait dan juga kebijakan pimpinan Madrasah yang bersangkutan. Sepandaipandainya seorang guru dan sebanyak apa pun pengalamannya dalam mengajar, tetap saja guru membutuhkan pembaruan, penyegaran, penguatan, 
dan peningkatan wawasan serta pengalamannya untuk dapat mengajar dengan lebih baik.

Selain dua kompetensi tersebut, guru juga harus menunjang dirinya dengan kompetensi personal dan kompetensi sosial. Kedua hal itu penting untuk memudahkan guru dalam bersosialisasi dan berinteraksi dengan anak-anak didiknya maupun dengan rekan sejawat sesama guru di komunitasnya. Dalam berinteraksi dengan para siswa, para guru mengaku tidak kesulitan dan bisa memahami dunia mereka jika terjadi sesuatu yang dapat mempengaruhi proses belajar siswa. Mereka menyadari pentingnya pendekatan kepada siswa agar dapat mudah diterima ketika memberikan motivasi dan dorongan belajar kepada siswa. Di dalam kelas, para guru juga mengaku sering menggunakan pendekatan yang lebih populis agar mereka dan pelajaran yang mereka ajarkan mudah diterima oleh para siswa. Di situlah terlihat kompetensi personal dan sosial mereka.

Di sisi yang lebih luas, para guru terlibat dalam forum sejawat guru bahasa Arab. Dalam forum semacam itu, mereka kerap berbagi informasi dan pengalaman serta memanfaatkan kesempatan untuk mencari solusi atas permasalahan pengajaran mereka selama ini di Madrasah masing-masing.

\section{Metode Pengajaran yang Digunakan}

Penguasaan guru terhadap metode pengajaran bahasa Arab mutlak menentukan kompetensi pedagogik mereka. Namun demikian, untuk memudahkan para guru dalam mengajar, kurikulum bahasa Arab nasional yang digunakan di Madrasah Aliyah telah memberikan panduan tentang metode pengajaran suatu materi dalam buku ajar yang dapat digunakan oleh para guru.

Meski suatu metode tertentu telah diarahkan dalam buku ajar, para guru mengaku sering terdorong untuk berimprovisasi dalam memilih dan menggunakan metode dalam pengajarannya. Itu antara lain terkait dengan situasi kelas manakala siswa terlihat kurang antusias dengan materi ajar ataupun metode pengajarannya. Alhasil, menurut para guru, penggunaan variasi metode tersebut membantu mereka untuk memahamkan siswa akan materi pelajaran dan mencapai tujuan pengajaran.

Metode memegang peranan penting dalam proses pengajaran kepada siswa. Guru memiliki kuasa penuh untuk memilih metode yang paling tepat digunakannya dalam mengajarkan bahasa Arab, bergantung pada situasi kelas, kondisi setiap siswa, latar sosial maupun ekonomi siswa, kultur masyarakat setempat, dan tentunya ketersediaan alat bantu pengajaran di sekolah yang bersangkutan. Guru diharapkan tidak kaku dalam memilih dan menerapkan metode pengajaran agar dapat mencapai hasil pembelajaran yang maksimal dari siswanya dan mencapai tujuan pengajaran yang dicanangkan.

\section{Waktu Pengajaran yang Tersedia di Dalam dan di Luar Kelas}

Jumlah jam pelajaran bahasa Arab menjadi pangkal segala permasalahan bagi sebagian besar guru. Mereka mengaku sulit bergerak di waktu yang tak lebih dari 2 s.d 4 jam sepekan. Mengingat banyaknya jumlah pelajaran lain dan padatnya jadwal dan jam belajar di sekolah, para guru harus memutar otak bila harus mengagendakan kegiatan tambahan di luar kelas. Itu pun harus seizin dan sepersetujuan pimpinan Madrasah. Itu membuat para guru tidak terlalu tertarik dan termotivasi untuk menjadwalkan kegiatan pengayaan pelajaran bahasa Arab. Selain itu, guru juga memahami tidak mungkin membebani siswa dengan hal-hal terkait pelajaran di luar jam belajar, baik di sekolah apalagi di luar sekolah. Kalaupun ada pekerjaan rumah yang diberikan, itu pun masih sebatas latihan terstruktur maupun latihan mandiri yang erat kaitannya dengan materi pelajaran. Tidak mudah memberikan tugas pengembangan kemampuan siswa di luar alokasi waktu yang ada di sekolah.

Meski begitu, para guru mengaku senang jika ada waktu khusus untuk program pengayaan yang dilakukan di sekolah dalam rangka peningkatan kemampuan bahasa Arab siswa. Para guru merasa benar-benar harus memanfaatkan sekecil apa pun kesempatan yang ada karena memang pentingnya hal itu bagi kemajuan belajar siswa dalam menguasai bahasa Arab. Tak pelak, situasi ini dapat menjadi motivasi tersendiri bagi para guru dalam memberikan yang terbaik kepada para siswanya.

\section{Lingkungan Berbahasa yang Mendukung Kemampuan Siswa}

Dalam pengajaran bahasa, termasuk bahasa Arab, lingkungan kebahasaan penting untuk mendorong kemampuan siswa. Lingkungan ini memang perlu diciptakan secara sadar dan dengan tujuan yang jelas sehingga manfaatnya dapat dirasakan oleh para siswa dan juga guru secara optimal.

Kesempatan paling baik yang ditemukan guru untuk dapat membentuk lingkungan berbahasa adalah saat ada kegiatan ekstrakurikuler bahasa Arab. Meski jumlah waktunya tidak banyak, 
mereka mengaku sebisa mungkin memanfaatkannya untuk mendorong siswa lebih aktif belajar bahasa Arab.

Kesulitan yang paling terasa adalah saat para guru mencoba mengajak siswa untuk lebih aktif berkomunikasi dalam bahasa Arab di luar kelas. Berbagai alasan dikemukakan oleh siswa untuk tidak mau aktif terlibat dalam hal ini, yang paling utama adalah rasa malas dan takut salah bicara atau salah kata, atau sebab lain misalnya malu dicemooh oleh teman-temannya sendiri. Situasi semacam itu sungguh tak menguntungkan dan perlu ditangani agar siswa tidak punya pandangan negatif saat dikondisikan oleh gurunya untuk lebih aktif dalam belajar bahasa Arab di luar kelas.

Salah satu tindakan yang dilakukan oleh para guru dan beberapa Madrasah mendukung hal itu adalah memberikan sanksi disiplin yang mendidik manakala ada kebijakan ataupun peraturan berbahasa Arab pada waktu dan tempat tertentu. Pada situasi ini, siswa dicoba untuk lebih berkomitmen dan berdisiplin sehingga terpacu untuk meningkatkan kemampuan bahasa Arab mereka di dalam maupun di luar kelas. Sanksi yang diberikan atas pelanggaran mereka pun masih seputar penugasan yang terkait dengan peningkatan kemampuan berbahasa, seperti menghafal sejumlah kata dalam kamus, menerjemahkan sebuah tulisan singkat berbahasa Arab ke dalam bahasa Indonesia, dan sebagainya.

\section{KESIMPULAN}

Berdasarkan analisis terhadap permasalahan pengajaran bahasa Arab di Madrasah Aliyah, khususnya yang berada di wilayah Jakarta, dapat disimpulkan bahwa pengajaran bahasa Arab pada level ini masih perlu ditingkatkan kualitasnya dengan menyelesaikan sejumlah permasalahan mendasar di dalamnya.

Dalam hal motivasi dan minat belajar bahasa Arab, siswa masih membutuhkan penanganan serius dan pendekatan khusus oleh para guru dan juga pimpinan Madrasah agar memandang bahasa Arab sebagai sesuatu yang penting dipelajari sebagai sebuah bidang ilmu dalam struktur ilmu keislaman dan karenanya para siswa senantiasa termotivasi dan berminat tinggi untuk mempelajarinya.

Motivasi dan minat itu juga menjadi dasar penting bagi penyelesaian masalah perbedaan individu siswa dalam pelajaran bahasa Arab. Perbedaan itu menjadi penghambat proses mengajar oleh guru dan karenanya pencapaian tujuan pengajaran serta hasil belajar bisa tidak maksimal. Ada siswa yang pernah belajar di level sekolah sebelumnya sehingga sudah mengenal dan relatif mudah menjalani pelajaran bahasa Arab di Madrasah Aliyah dan ada pula kelompok siswa yang baru mengenal pelajaran bahasa Arab karena sebelumnya sekolah di Sekolah Menengah Pertama umum/nonkeagamaan.

Faktor lain yang berkaitan dengan masalah pada pengajaran bahasa Arab adalah ketersediaan sarana penunjang pengajaran. Masih ada fasilitas belajar yang tersedia tapi tidak termanfaatkan secara efektif dan optimal, sementara di Madrasah lain tidak ada sarana belajar yang memadai sehingga proses pengajaran harus dilakukan dengan pendekatan konvensional yang terkadang diperkaya dengan inovasi sang guru.

Keberadaan guru yang berkualifikasi baik mutlak diperlukan. Namun, pada kenyataannya masih ada guru yang bukan berlatar pendidikan bahasa Arab dan juga minim wawasan dan pengalaman terkini, sehingga membutuhkan program pengembangan lebih lanjut. Untungnya, para guru menyadari bahwa betapa pun terbatasnya sarana di sekolah, dia harus tetap menunjukkan profesionalisme sebagai pribadi yang pantas untuk menjadi teladan dan dekat dengan para siswanya demi memotivasi semangat belajar mereka. Mereka pun berusaha aktif dalam forum-forum rekan sejawat untuk menambah informasi dan berbagi pengalaman sesama.

Informasi dan pengalaman itu penting dalam rangka menjalankan proses pengajaran dengan metode dan pendekatan yang tepat. Para guru berusaha tidak kaku mengikuti panduan buku dan kurikulum yang telah menggariskan metode tertentu dalam pengajaran sehingga mampu membuat suasana belajar di kelas lebih variatif dan dapat diterima dengan baik oleh para siswa.

Pembelajaran di kelas menjadi kunci pencapaian tujuan pengajaran dan hasil belajar yang maksimal. Itu karena minimnya waktu yang tersedia untuk menambah kegiatan belajar baik di dalam maupun di luar kelas. Kalau pun ada kegiatan tambahan, maka guru sebisa mungkin memanfaatkannya untuk meningkatkan kemampuan siswa dalam taraf tertentu.

Terkait dengan minimnya waktu belajar, masih minim pula keseriusan pihak Madrasah maupun siswa untuk bersama-sama membentuk dan menciptakan lingkungan belajar yang mendorong 
kemajuan dalam penguasaan bahasa Arab. Dampaknya adalah minimnya aktivitas tambahan yang sesungguhnya bermanfaat bagi semua pihak untuk meningkatkan kemampuan berbahasa Arab siswa.

\section{DAFTAR PUSTAKA}

\section{Buku yang diedit}

[1] Pusat Penelitian dan Pengembangan Pendidikan Islam, Badan Penelitian dan Pengembangan, Departemen Agama Republik Indonesia, "Laporan Penelitian Survei Kemampuan Membaca Bahasa Arab Siswa Madrasah Aliyah di Indonesia”, h.103105, 2007.

\section{Publikasi elektronik, informasi dari internet}

[2] S. Fiddaroini, "Bahasa Arab: Mengidentifikasi Problem Pendidikan Bahasa Arab", 2010. [Online]. Available: http://saidunfiddaroini.blogspot.com/201 0/07/bahasa-arabmengidentifikasi-problem.html [Accessed 24 Mei 2014].

\section{Prosiding}

[3] Alim, Ghufron Zainal. As-Syu'ubat al-Lati Tuwajihu Darisi al-Lughah al- 'Arabiyah Fi al-Jami'ah alIndunisiyah Wa Subulu at-Taghallub 'Alaiha. Makalah Seminar Pengembangan Pengajaran Bahasa Arab di Perguruan Tinggi Indonesia, Surabaya. h.6-7, 1992.

\section{Majalah}

[4] I. Saadah, "Problematika Pengajaran Bahasa Arab dan Solusinya", Mimbar Pembangunan Agama, Surabaya: Kantor Wilayah departemen Agama Propinsi Jawa Timur, h.62, 1997.

[5] U. Masduki, "Problematika Pengajaran Bahasa Arab di Madrasah Aliyah", Ikhlas Beramal No. 7 Th. II. Jakarta: Departemen Agama RI, h.53-55, 1997.

\section{Buku}

[6] A. Fakhrurrozi, E. Mahyudin, Pembelajaran Bahasa Arab. Jakarta: Direktorat Jenderal Pendidikan Islam Kementerian Agama RI, h.6-10, 2012. 